\title{
Click, print, fire: 3D printing and the Arms Trade Treaty
}

\author{
ALEX CATALÁN FLORES
}

\section{Abstract}

On 3 June 2013, countries united to sign the Arms Trade Treaty (ATT) in an effort to combat illegal arms transfers and regulate legal arms transfers between countries. The ATT provides an unprecedented regulatory framework that encompasses previously unregulated military materiel such as combat aircraft and battle tanks. However, exactly one month earlier, a new threat emerged when shots were fired from the world's first entirely 3D-printed plastic polymer firearm-the Liberator. On 12 May, two Daily Mail journalists printed a copy of the Liberator and smuggled it past airportstyle security. Despite this threat, 3D-printed firearms are not mentioned in either the treaty negotiations or the final treaty text. This article analyses whether the legal architecture provided by the ATT can address the three main challenges posed by $3 \mathrm{D}$ printing: firearms, components and digital design files. This article reviews the ATT through the lens of international disarmament law and international institutional law, analysing commentary from superior international courts and eminent legal scholars. Ultimately, this article posits that while the ATT adequately addresses 3D-printed firearms, it creates a legal void in the space of 3D-printed components and digital design files, meaning that weapons can still be transferred by sending them component by component or by sharing the original design file online. A solution is possible within the current parameters of international law, but this will depend on states' willingness to give proactive legal powers to the ATT's primary organ-the Conference of States Parties.

\section{Introduction}

The Arms Trade Treaty (ATT) was signed on 3 June 2013 by an initial 67 states, a number that today has increased to $130 .^{1}$ As of 29 May 2016, 82 of these signatories will be States Parties to the ATT, bound by its full scope of rights and

1 Arms Trade Treaty, opened for signature 3 June 2013, [2014] ATS 42 (entered into force 24 December 2014). 
obligations. ${ }^{2}$ However, on 3 May 2013, one month before the ATT was initially signed, the founder of Defense Distributed, Cody Wilson, shot the first entirely 3D-printed plastic polymer firearm, christened the Liberator. This new generation of firearms caught the world's attention because of its innovative method of manufacturing; giving the user the ability to produce an unregulated firearm from the privacy of their home, unbeknownst to the legal system. As this manufacturing technology becomes more accessible, ${ }^{3}$ world powers are looking to international regulatory regimes as a source of stability and security.

This article critically analyses whether the legal architecture provided by the ATT is capable of tackling the challenges posed by $3 \mathrm{D}$ printing. The scope of this article will be limited to examining the legal interaction between the ATT and 3D-printed firearms, more specifically small arms and light weapons (SALW), as well as parts and components, excluding ammunition and munitions. The reason for this is that, to date, there has not been a report of successful manufacture and testing of 3D-printed ammunition or munitions, and so it cannot be claimed the ATT faces this as a contemporary challenge. ${ }^{4}$

This article will first provide an overview of the international regulatory regime as it applies to SALW before briefly summarising 3D-printing technology and its use to manufacture firearms and components. This will then be followed by a legal analysis of the ATT's scope of application, focusing on whether the legal reach of the ATT extends to cover 3D-printed firearms and components, as well as digital computeraided design (CAD) files. To conclude, this article will provide possible avenues of redress to the legal issues raised, with particular emphasis on the international institutions created under the ATT.

\section{The regulation of SALW}

The regulation of SALW as well as firearm components can be traced to the adoption of the 2001 Protocol against the Illicit Manufacturing of and Trafficking in Firearms, Their Parts and Components and Ammunition. ${ }^{5}$ The Protocol is a legally binding instrument focusing on 'the need to prevent and control illicit activities commonly involving firearms that are associated with organized crime groups' ${ }^{6}$ The emphasis of the Protocol was to be crime prevention and law enforcement,

\footnotetext{
2 United Nations Office for Disarmament Affairs, ATT Status of Ratifications and Accessions, s3.amazonaws.com/ unoda-web/wp-content/uploads/2013/06/ATT-status-table-WebReport-2-Mar-2016.pdf.

3 N.R. Jenzen-Jones, 'Small Arms and Additive Manufacturing: An Assessment of 3D-printed Firearms, Components and Accessories' (Occasional Paper No. 32, Small Arms Survey, February 2015), 55-8.

4 Ibid., 64.

5 Protocol against the Illicit Manufacturing of and Trafficking in Firearms, Their Parts and Components and Ammunition, opened for signature 31 May 2001, 2326 UNTS 208 (entered into force 3 July 2005).

6 Sarah Parker and Marcus Wilson, A Diplomat's Guide to the UN Small Arms Process (Small Arms Survey, 2nd ed., 2014), 32.
} 
consequently steering away from the more central issues relating to arms control. ${ }^{7}$ These issues were delegated to the 2001 UN Small Arms Conference, from which stemmed the Programme of Action to Prevent, Combat and Eradicate the Illicit Trade in Small Arms and Light Weapons in All Its Aspects (PoA). ${ }^{8}$ As a 'politically binding instrument', ${ }^{9}$ the PoA contains similar themes to the Protocol in terms of reducing human suffering, but the focus of its provisions is geared towards eradicating illicit trade rather than crime prevention. The PoA addressed areas excluded by the Protocol, ${ }^{10}$ and also introduces voluntary reporting requirements and a sexennial review conference aimed at evaluating state implementation of the PoA. ${ }^{11}$ Despite this seemingly progressive movement towards a more comprehensive international instrument, 'soft questions' in the areas of human rights and the humanitarian effects of illicit trade were ultimately excluded. ${ }^{12}$ Since its adoption, the PoA has been complemented by subsequent international instruments, including the International Instrument to Enable States to Identify and Trace, in a Timely and Reliable Manner, Illicit Small Arms and Light Weapons (ITI) and the ATT. ${ }^{13}$

Adopted in 2005, the ITI is another 'politically binding instrument' that advances issues of weapons marking, record-keeping and international cooperation with respects to tracing and implementation. ${ }^{14}$ It is important to highlight that the ITI provided the international community with its first explicit definition of SALW. ${ }^{15}$ The following year, the UN General Assembly adopted Resolution 61/89, calling on states to explore the feasibility and scope of a legally binding multilateral instrument aimed at regulating the international transfers of conventional arms. ${ }^{16}$ This ultimately became the ATT, overwhelmingly adopted by the UN General Assembly on 2 April 2013 and opened for signature on 3 June 2013. The ATT represents a culmination of state interests regarding the regulation of international arms transfers, establishing the highest relevant regulatory legal instrument. ${ }^{17}$ 'The ATT's place as the 'highest' instrument in this area makes it this article's focus.

\footnotetext{
$7 \quad$ Ibid., 37.

8 Programme of Action to Prevent, Combat and Eradicate the Illicit Trade in Small Arms and Light Weapons in All Its Aspects, UN Doc A/CONF.192/15 (20 July 2001).

9 Parker and Wilson, above n 6, 39.

10 Parker and Wilson, above n 6, 35.

11 Parker and Wilson, above n 6, 50; Programme of Action II(33), IV(1)(a).

12 Parker and Wilson, above n 6, 45.

13 International Instrument to Enable States to Identify and Trace, in a Timely and Reliable Manner, Illicit Small Arms and Light Weapons, UN Doc A/60/88 (27 June 2005) Annex I.

14 Parker and Wilson, above n 6, 52, 55.

15 International Tracing Instrument II(4).

16 Towards an Arms Trade Treaty: Establishing Common International Standards for the Import, Export and Transfer of Conventional Arms, GA Res 61/89, UN GAOR, 1st Comm, 61st sess, 67th mtg, Agenda Item 90, UN Doc A/ RES/61/89 (18 December 2006).

17 Arms Trade Treaty art 1.
} 


\section{D-printed firearms, components and the law}

\section{The development of 3D-printed firearms and components}

Originally developed in the 1980s, 3D-printing technology has been 'limited to lowvolume industrial manufacturing (most commonly for rapid prototyping) because of financial and technological considerations'. ${ }^{18} 3 \mathrm{D}$ printing is a colloquialism for what the manufacturing industry refers to as additive manufacturing. ${ }^{19}$ Industry actors use a variety of different additive manufacturing technologies including stereolithography, fused deposition modelling, and direct metal laser sintering (DMLS).$^{20}$ In the context of the firearms industry, 3D-printing processes have been used for prototyping since the 1990s. ${ }^{21}$ The technology came to the forefront of the arms discourse when in 2013 Defense Distributed developed and successfully fired a .380 single-shot Automatic Colt Pistol made entirely from a plastic polymer, known as the Liberator. ${ }^{22}$ By the end of 2013, another industry actor, Solid Concepts, produced an almost identical metal copy of the Colt M1911 semi-automatic pistol using DMLS technology. ${ }^{23}$ Solid Concepts attests its 1911 DMLS is capable of firing over 4,500 rounds without the need to replace any parts. ${ }^{24}$ In terms of additively manufactured firearm components, there are several manufacturers involved in the production of structural (such as lower receivers for AR-15 type rifles) and nonstructural components (such muzzle breaks or pistol grips). ${ }^{25}$

\section{Interactions with the ATT}

The primary question when analysing the legal interaction between the ATT and 3D-printed firearms and components is one of definition. The type of 3D-printed firearms so far discussed would be classified as SALW, ${ }^{26}$ which in the absence of an internal definitional provision requires resorting to the Vienna Convention on the Law of Treaties (VCLT). ${ }^{27}$ Pursuant to the general rule of interpretation, Article 2(1)(h) of the ATT is to be interpreted in good faith in accordance with the ordinary meaning to be given to the terms of the treaty in their

18 Jenzen-Jones, above n 3, 44-5.

19 'The printed world', The Economist (London), 12 February 2011 [4].

20 Jenzen-Jones, above n 3, 47-50.

21 Ibid., 45-6.

22 Ibid., 50.

23 Ibid., 52.

24 Ibid., 52-3.

25 Ibid., 46, 53.

26 Arms Trade Treaty art 2(1)(h).

27 Vienna Convention on the Law of Treaties, opened for signature 23 May 1969, 1155 UNTS 331 (entered into force 27 January 1980) ('Vienna Convention'). 
context and in light of its object and purpose. ${ }^{28}$ Whilst the ordinary meaning of the words in Article 2(1)(h) by themselves provide a definition based on size and weight, the context in which the ATT arose can further clarify the meaning of the provision. Reference to the preamble of the ATT provides a guide to defining this context, ${ }^{29}$ particularly because it notes the contribution made by the ITI. ${ }^{30}$ The ITI provides an express definition for SALW, ${ }^{31}$ within which a 3D-printed firearm such as the Liberator or the 1911 DMLS would be classified as a 'small arm' because it is a man-portable lethal weapon for individual use that expels a bullet by the action of an explosive. ${ }^{32}$ Thus, the method of manufacture of 3D-printed firearms is inconsequential as to whether they fall within the scope of the ATT.

The question of 3D-printed components is significantly more complicated. Components fall within the separate scope of Article 4, and the ordinary meaning of the words 'part' and 'component' in the provision would easily encompass 3D-printed components such as those thus far discussed. The complication arises from the subsequent words in Article 4 stating that the only exports of components that States Parties are required to regulate are those where 'the export is in a form that provides the capability to assemble the conventional arms covered under Article 2(1)'. ${ }^{33}$ Initially, the ordinary meaning of Article 4 appears to create a regulatory loophole, which is best illustrated with an example. In the event that a package of disassembled 3D-printed Liberators is transferred between two States Parties, such a transfer would fall within the scope of Article 4, consequently triggering obligations under Articles 5, 6 and 7. However, if such a transfer were to take place in successive shipments, each containing a separate Liberator component, then each shipment in and of itself does not give rise to assembly capability, and thus Article 4 would not be triggered. This oversight has already been the subject of critique in the literature, ${ }^{34}$ attributing it to practical considerations raised by leading arms-exporting states during the ATT negotiations. ${ }^{35}$ Nevertheless, one interpretation is that states' good faith obligations, as enshrined in the VCLT, ${ }^{36}$ would prevent the exploitation of this loophole. ${ }^{37}$ This analysis warrants further examination, as it appears to suggest that Article 4 can be alternatively interpreted

\footnotetext{
28 Vienna Convention art 31.

29 Vienna Convention art 31(2).

30 Arms Trade Treaty preamble [8].

31 International Tracing Instrument $\mathrm{II}(4)$.

32 International Tracing Instrument II(4)(a).

33 Arms Trade Treaty art 4.

34 Laurence Lustgarten, 'The Arms Trade Treaty: Achievements, Failings, Future' (2015) 64 International and Comparative Law Quarterly 569, 598; Stuart Casey-Maslen, Gilles Giacca and Tobias Vestner, 'The Arms Trade Treaty (2013)' (Academy Briefing No 3, Geneva Academy of International Humanitarian Law and Human Rights, June 2013) 21.

35 Lustgarten, above n 34, 584.

36 Vienna Convention arts 26, 31(1).

37 Casey-Maslen, Giacca and Vestner, above n 34, 21.
} 
in spite of the clear ordinary meaning of its terms. A 'good faith' interpretation of a provision can be an elusive exercise ${ }^{38}$ but there is considerable authority to suggest that:

Good faith ... means more than simply bona fides in the sense of absence of mala fides, or rejection of an interpretation resulting in abuse of rights (though, of course, it includes such absence and rejection). It signifies an element of reasonableness qualifying the dogmatism that can result from purely verbal analysis. ${ }^{39}$

A purely verbal analysis of Article 4 yields a construction wherein circumvention of obligations is a real possibility, even in the absence of mala fides. The question then arises as to whether such a literalist construction where Article 4 is essentially left devoid of any practical effect is in fact a good faith construction in light of the object and purpose of the ATT. ${ }^{40}$ This is what the jurisprudence has characterised as the fundamental principle of effectiveness (or 'effet utile'), the content of which stipulates that provisions should be interpreted so as to render them effective. ${ }^{41}$ However, interpreting Article 4 so as to neutralise the potential for circumvention and thereby render it effet utile would be an excessively intrusive exercise, as it would require reading into the provision an opposing meaning to the ordinary meaning of the terms. Such an alternative construction would be contrary to the 'letter and spirit' of the provision. ${ }^{42}$ In light of this, adherence to a literalist interpretive approach of Article 4, where circumvention of obligations can be so easily conceived, could be argued to be a 'manifestly absurd or unreasonable result'. ${ }^{43}$ In this case, recourse can be had to supplementary means of interpretation, such as the travaux préparatoires, in order to determine the meaning of Article $4 .{ }^{44} \mathrm{~A}$ comprehensive study of the travaux préparatoires is beyond the scope of this article, but it should be noted that the courts have approached this avenue of interpretation with particular caution. In Competence of the General Assembly for the Admission of a State to the United Nations, the International Court of Justice stated:

38 Richard K. Gardiner, Treaty Interpretation (Oxford University Press, 2008), 150.

39 Ibid., 151 (emphasis original).

40 Cf. Gardiner, above n 34, 160, quoting 'Report of the International Law Commission on the work of its eighteenth session' (1966) II(2) Yearbook of the International Law Commission 169, 219 [6].

41 Corfu Channel Case (United Kingdom v. Albania) (Merits) [1949] ICJ Rep 4, 24; Legal Consequences for States of the Continued Presence of South Africa in Namibia (South West Africa) notwithstanding Security Council Resolution 276 (1970) (Advisory Opinion) [1971] ICJ Rep 16, 35 [66]; Territorial Dispute (Libyan Arab Jamahiraya v. Chad) [1994] ICJ Rep 6, 25 [51].

42 Interpretation of Peace Treaties with Bulgaria, Hungary and Romania (Advisory Opinion) [1950] ICJ Rep 221, 229.

43 Vienna Convention art 32(b).

44 Vienna Convention art 32(b). 
[T] he first study of a tribunal which is called upon to interpret and apply provisions of a treaty, is to endeavour to give effect to them in their natural and ordinary meaning in the context in which they occur. If the relevant words in their natural and ordinary meaning make sense in their context, that is the end of the matter. If, on the other hand, the words in their natural and ordinary meaning are ambiguous or lead to an unreasonable result, then, and then only, must the Court, by resort to other method of interpretation, seek to ascertain what the parties really did mean when they used these words. ${ }^{45}$

While it is recognised that an exception to the rule that the ordinary meaning of the terms must prevail exists in the instance of absurdity or unreasonableness, the Court is firm in its language and appears to set a high threshold for this supplementary method of interpretation. Additionally, the International Law Commission (ILC) emphasises that Article 32 is supplementary in nature, and does not provide for 'alternative, autonomous, means of interpretation but for means to aid an interpretation governed by the principles contained in Article [31].${ }^{46}$ It is for this reason that, whilst the above literalist construction of Article 4 of the ATT can seem absurd or unreasonable, Article 32 of the VCLT cannot provide us with an alternative avenue of autonomous interpretation. The ordinary meaning of Article 4 is, in light of its context, sufficiently clear and settled.

As a final point relating to components, the literature has criticised the complete exclusion of 'Technology and Equipment' from the scope of the treaty, ${ }^{47}$ as originally envisioned by the framers. ${ }^{48}$ This exclusion raises the question of whether CAD files used by $3 \mathrm{D}$ printers could potentially be covered under Article 4 as 'components', similarly to the manner in which the United States Munitions List refers to 'technical data' used in the manufacture or production of firearms. ${ }^{49}$ The ordinary meaning of Article 4, in its context, suggests that only physical parts and components are within its scope. In the extreme, the terms of Article 4 could be claimed as ambiguous and in need of supplementary interpretation, but in that case it is clear from the transition between an initial 12 categories to the current eight that States Parties actively intended to exclude technology from the scope of the treaty. Consequently, it can conclusively be stated that CAD files and any other similar digital file involved in the additive manufacture of firearms are not covered by the ATT.

45 Competence of the General Assembly for the Admission of a State to the United Nations [1950] ICJ Rep 6, 4 (emphasis added).

46 'Report of the International Law Commission on the work of its eighteenth session' (1966) II(2) Yearbook of the International Law Commission 169, 223 [19].

47 Lustgarten, above n 34, 582-3.

48 Ibid., 579.

49 International Traffic in Arms Regulations, Foreign Relations 22 CFR $\$ 121.1$ (2016). 


\section{Institutional responses}

\section{Characterisation}

The legal issues raised above are intrinsic to the treaty provisions themselves. Consequently, any form of progressive reform would require the terms of the ATT be varied or reinterpreted in some manner. The Conference of States Parties $(\mathrm{CSP})^{50}$ is best placed to adapt the provisions of the treaty for the reality posed by 3D-printing technology. To this end, the ATT grants the CSP crucial powers, such as, inter alia, powers of interpretation and power to consider amendments. ${ }^{51}$ Each of these is considered below, but first the legal character of the CSP must be examined, so as to determine whether it is an international organisation (IO) with international legal personality. Whether this is the case has crucial implications, as Worster delineates:

an important result of considering the ATT as creating an international organization is that the doctrine of implied powers, ultra vires, and the 'constitutional' interpretation of the constitutive instruments apply. Furthermore, entities governed by international institutional law can generally influence the interpretation of the treaty themselves through their institutional practice ... If, however, principles of international institutional law do not apply to these entities, then the normal rules of treaties apply (the treaty could be considered 'self-contained'). ${ }^{52}$

The ILC has advanced a definition for IOs as an organisation established under an instrument governed by international law and possessing its own international legal personality. ${ }^{53}$ An organisation's international legal personality needs to be 'distinct from that of its member States, ${ }^{54}$ which can also be interpreted as the organisation possessing its 'own' legal personality. ${ }^{55}$ Similarly, Schremers and Blokker define IOs as forms of cooperation founded on international agreement, with at least one organ with a will of its own, and established under international law. ${ }^{56}$ Of these three elements provided by Schremers and Blokker, the CSP prima facie satisfies the first and third, in that it has emerged from an international agreement (Article 17 of the ATT) and, therefore, it can be assumed that it was established under the auspices of international law. ${ }^{57}$ As for the second element, whether the CSP has a will of its

50 Arms Trade Treaty art 17.

51 Ibid., art 17(4).

52 William Thomas Worster, 'The Arms Trade Treaty Regime in International Institutional Law' (2015) 36 Pennsylvania Journal of International Law 995, 1008 (emphasis original) (footnotes omitted).

53 'Report of the International Law Commission on the work of its sixty-third session' (2011) II(2) Yearbook of the International Law Commission 52, 54.

54 Ibid., 75-6.

55 Ibid.

56 Henry G. Schermers and Niels M. Blokker, International Institutional Law (Martinus Nijhoff Publishers, 5th ed., 2011) 37 [33].

57 Ibid., 47 [45]. 
own, the answer is best discerned from determining whether the CSP is a treaty organ (TO). This is because TOs can be distinguished from IOs as they are not usually independent legal persons. ${ }^{58}$ The CSP resembles a TO because it is the direct product of a treaty and not established by a constituent instrument or a resolution. ${ }^{59}$

Nonetheless, the architecture of the ATT is such that the contrary can also be justifiably advanced. In describing them as 'autonomous institutional arrangements', Churchill and Ulfstein refer to plenary organs such as Conferences of the Parties under various multilateral environmental agreements as possessing international legal personality and, consequently, effectively characterising them as IOs. ${ }^{60}$ By way of example, the UN Framework Convention on Climate Change establishes a Conference of the Parties that, in agreement with Churchill and Ulfstein, ${ }^{61}$ the UN Office of Legal Affairs has asserted is 'an international entity/organization with its own separate legal personality, statement of principles, organs and a supportive structure in the form of a Secretariat' ${ }^{62}$ A direct corollary can be drawn to the CSP in that it is also established together with a statement of principles and a supportive secretariat. ${ }^{63}$ Further factors pointing towards autonomy include the fact that the CSP does not follow instructions from any particular State Party, ${ }^{64}$ and also the wide range of unique powers granted to it by the ATT, in comparison to other arms control instruments. ${ }^{65}$

The above analysis demonstrates that a definitive determination on the matter proves to be a difficult exercise. Ultimately, the hybrid nature of the CSP lends itself best to the view of the International Law Association that TOs are incomplete international organizations' ${ }^{66}$ The remainder of this article will adopt Worster's assumption, ${ }^{67}$ namely that general principles of international institutional law apply to the CSP in those areas where it acts akin to an IO, such as in exercising its powers under Article 20.

\footnotetext{
58 Ibid., 45 [44].

59 Paul C. Sasz, 'The Complexification of the United Nations System' (1999) 3 Max Planck Yearbook of United Nations Law 1, 18.

60 Robin R. Churchill and Geir Ulfstein, 'Autonomous Institutional Arrangements in Multilateral Environmental Agreements: A Little-Noticed Phenomenon in International Law' (2000) 94 American Journal of International Law $623,626,655$.

61 Worster, above n 52, 1007.

62 'Legal capacity of the Conference of the Parties to the Convention and the Global Environment Facility to enter into an agreement or other arrangement with third parties and the legal nature of such agreement or arrangement' [1993] II(4) United Nations Juridical Yearbook 427, 428 [4].

63 Arms Trade Treaty preamble, art 18.

64 Worster, above n 52, 1009, citing Finn Seyersted, 'Objective International Personality of Intergovernmental Organizations' (1964) 34 Nordic Journal of International Law 3, 47.

65 Worster, above n 52, 1010.

66 Ibid., 1009, citing International Law Association, 'Final Report from the Committee on the Accountability of International Organizations' (2004) 1 International Organizations Law Review 221, 241.

67 Worster, above n 52, 1011.
} 


\section{Powers of the CSP}

\section{Considering amendments}

Under the ATT, the CSP is tasked with the consideration of amendments to the treaty in accordance with Article $20 .{ }^{68}$ An amendment would have to have the effect of modifying Article 4 so as to resolve the circumvention issue, as well as provide clarity on the matter of digital CAD files. At first instance, the CSP is unable to act because under Article 20 there is a moratorium on amendments to the ATT for six years, making the earliest possible date for the proposal of an amendment 24 December 2020. ${ }^{69}$ Further, Article 20 creates a high threshold for the adoption of amendments, requiring consensus from States Parties or, as a last resort, a majority of three-quarters of those present and voting. ${ }^{70} \mathrm{~A}$ close examination of its amendment power, as circumscribed by Article 20, suggests the CSP does not possess the authority to act independently on matters of amendment, in essence making it a 'forum for discussing the need for amendments' as opposed to a more powerful entity such as those found under some environmental treaties. ${ }^{71}$ For example, under the Convention on International Trade in Endangered Species of Wild Fauna and Flora, only one-third of States Parties is needed to convene a meeting to consider an amendment, which can subsequently be adopted by a two-thirds majority. ${ }^{72}$ In light of this, the focus turns to the CSP's power to consider issues regarding interpretation, which are arguably broader. ${ }^{73}$

\section{Interpreting the ATT}

The CSP is given power to consider issues arising from the interpretation of the ATT. ${ }^{74}$ It is uncertain if this allows the CSP to provide definitive interpretations of the meaning of certain provisions, ${ }^{75}$ so as to, for example, interpret Article 4 to include digital CAD files. In order to discern the intention of the framers of the ATT, Article 17(4)(d) should be interpreted in light of its context, specifically the rest of the treaty text. ${ }^{76}$ In this sense, Article 19 places a potentially crucial qualification on the CSP's powers of interpretation, in that it directs parties to seek external dispute resolution in the event of a dispute with the interpretation of the ATT. ${ }^{77}$ This suggests the intention of the framers was not to allow Article 17(4)(d)

68 Arms Trade Treaty art 17(4)(c).

69 Ibid., art 20(1).

70 Ibid., art 20(3).

71 Worster, above n 52, 1038

72 Convention on International Trade in Endangered Species of Wild Fauna and Flora, opened for signature 3 March 1973, 993 UNTS 243 (entered into force 1 July 1975) art XVII.

73 Worster, above n 52, 1040.

74 Arms Trade Treaty art 17(4)(d).

75 Worster, above n 52, 1037.

76 Vienna Convention art 31(2).

77 Arms Trade Treaty art 19(1), (2). 
to confer definitive and final powers of interpretation on the CSP. However, the CSP's powers are not limited to those expressly provided in the ATT. In addition to its express powers, the CSP must also be deemed to have those powers that are 'conferred upon it by necessary implication as being essential to the performance of its duties'. ${ }^{78}$ The extent to which the CSP would be conferred implied powers is limited by the principle of speciality, the content of which specifies that an international institution with a special purpose only has functions bestowed upon it with a view of fulfilling that special purpose. ${ }^{79}$ Consequently, in order to be able to review the developments in the field of conventional arms, ${ }^{80}$ as well as to achieve the ATT's broader humanitarian purpose ${ }^{81}$ it is essential that the CSP be conferred the power to make definitive interpretations of the provisions of the ATT with regards to the implications of 3D-printing technology. Such an implied power would not be 'tantamount to disregarding the principle of speciality' as it would remain contained within the parameters of arms trade regulation. ${ }^{82}$

\section{Conclusion}

This article has provided a critical appraisal of the scope of application of the ATT with regards to additively manufactured firearms and components, as well as the $\mathrm{CAD}$ files required to manufacture them. Whilst a historic landmark in the development of international conventional arms control, the ATT performance in the face of $3 \mathrm{D}$ printing is unsatisfactory. Whilst 3D-printed firearms aptly fall within the legal reach of the ATT, components and CAD files fall squarely outside it, consequently generating a legal void yet to be addressed by the international community. In saying this, the legal architecture of the ATT is such that an internal institutional solution is conceivable, by way of the CSP using the broad powers with which it is bestowed. This will, however, depend on the willingness of States Parties to permit the CSP to assume the proactive role of an autonomous IO.

78 Reparation for Injuries Suffered in the Service of the United Nations (Advisory Opinion) [1949] ICJ Rep 174, 182-3.

79 Legality of the Use by a State of Nuclear Weapons in Armed Conflict (Advisory Opinion) [1996] ICJ Rep 66, 78-9 ('Legality of the Use of Nuclear Weapons').

80 Arms Trade Treaty art 17(4)(a).

81 Ibid., art 1.

82 Legality of the Use of Nuclear Weapons 79. 


\section{Bibliography}

\section{Articles/books/reports}

Casey-Maslen, Stuart, Gilles Giacca and Tobias Vestner, 'The Arms Trade Treaty (2013)' (Academy Briefing No 3, Geneva Academy of International Humanitarian Law and Human Rights, June 2013).

Churchill, Robin R. and Geir Ulfstein, 'Autonomous Institutional Arrangements in Multilateral Environmental Agreements: A Little-Noticed Phenomenon in International Law' (2000) 94 American Journal of International Law 623.

Conference of States Parties, Arms Trade Treaty, Final Report of the First Conference of States Parties, UN Doc ATT/CSP1/2015/6 (27 August 2015).

Gardiner, Richard K., Treaty Interpretation (Oxford University Press, 2008).

International Law Commission, 'Report of the International Law Commission on the work of its eighteenth session' (1966) II(2) Yearbook of the International Law Commission 169.

International Law Commission, 'Report of the International Law Commission on the work of its sixty-third session' (2011) II(2) Yearbook of the International Law Commission 52, 54.

Jenzen-Jones, N.R., 'Small arms and additive manufacturing: An assessment of 3D-printed firearms, components and accessories' (Occasional Paper No. 32, Small Arms Survey, February 2015).

Lustgarten, Laurence, 'The Arms Trade Treaty: Achievements, Failings, Future' (2015) 64 International and Comparative Law Quarterly 569.

Parker, Sarah and Marcus Wilson, A Diplomat's Guide to the UN Small Arms Process (Small Arms Survey, 2nd ed., 2014).

Sasz, Paul C., 'The Complexification of the United Nations System' (1999) 3 Max Planck Yearbook of United Nations Law 1.

Schermers, Henry G. and Niels M. Blokker, International Institutional Law (Martinus Nijhoff Publishers, 5th ed., 2011).

United Nations Office of Legal Affairs, 'Legal capacity of the Conference of the Parties to the Convention and the Global Environment Facility to enter into an agreement or other arrangement with third parties and the legal nature of such agreement or arrangement' [1993] II(4) United Nations Juridical Yearbook 427.

Walther, Gerald, 'Printing Insecurity? The Security Implications of 3D-Printing of Weapons' (2015) 21 Science and Engineering Ethics 1435. 
Worster, William Thomas, 'The Arms Trade Treaty Regime in International Institutional Law' (2015) 36 Pennsylvania Journal of International Law 995.

\section{Cases}

Certain Expenses of the United Nations (Article 27, paragraph 2, of the Charter) (Advisory Opinion) [1962] ICJ Rep 151.

Competence of the General Assembly for the Admission of a State to the United Nations [1950] ICJ Rep 6.

Corfu Channel Case (United Kingdom v. Albania) (Merits) [1949] ICJ Rep 4.

Interpretation of Peace Treaties with Bulgaria, Hungary and Romania (Advisory Opinion) [1950] ICJ Rep 221.

Legal Consequences for States of the Continued Presence of South Africa in Namibia (South West Africa) notwithstanding Security Council Resolution 276 (1970) (Advisory Opinion) [1971] ICJ Rep 16.

Legality of the Use by a State of Nuclear Weapons in Armed Conflict (Advisory Opinion) [1996] ICJ Rep 66.

Reparation for Injuries Suffered in the Service of the United Nations (Advisory Opinion) [1949] ICJ Rep 174.

Territorial Dispute (Libyan Arab Jamahiraya v. Chad) [1994] ICJ Rep 6.

Whaling in the Antarctic (Australia v. Japan) (Judgment) [2014] ICJ Rep 226.

\section{Treaties}

Arms Trade Treaty

Convention on International Trade in Endangered Species of Wild Fauna and Flora

International Instrument to Enable States to Identify and Trace, in a Timely and Reliable Manner, Illicit Small Arms and Light Weapons

International Traffic in Arms Regulations

Programme of Action to Prevent, Combat and Eradicate the Illicit Trade in Small Arms and Light Weapons in All Its Aspects

Protocol against the Illicit Manufacturing of and Traffcking in Firearms, Their Parts and Components and Ammunition

Vienna Convention on the Law of Treaties 
This text is taken from The ANU Undergraduate Research Journal, Volume Eight, 2016, edited by Daniel McKay, published 2017 by ANU eView, The Australian National University, Canberra, Australia.

dx.doi.org/10.22459/AURJ.08.2016.15 